Review

\title{
Roman to Middle Age Earthquakes Sourced by the 1980 Irpinia Fault: Historical, Archaeoseismological, and Paleoseismological Hints
}

\author{
Paolo Galli 1,2 \\ 1 Dipartimento della Protezione Civile, Via Vitorchiano 4, 00189 Rome, Italy; paolo.galli@protezionecivile.it \\ 2 CNR-IGAG, Via Salaria km 29,300, 00015 Monterotondo Stazione (Rome), Italy
}

Received: 11 June 2020; Accepted: 22 July 2020; Published: 27 July 2020

\begin{abstract}
The Italian seismic compilations are among the most complete and back-in time extended worldwide, with earthquakes on record even before the Common Era. However, we have surely lost the memory of dozen strong events of the historical period, mostly in the first millennium CE. Given the lack of certain or conclusive written sources, besides paleoseismological investigations, a complementary way to infer the occurrence of lost earthquakes is to cross-check archaeoseismic evidence from ancient settlements. This usually happens by investigating collapses/restorations/reconstructions of buildings, the general re-organization of the urban texture, or even the abrupt abandonment of the settlement. Exceptionally, epigraphs mentioning more or less explicitly the effects of the earthquake strengthened the field working hypothesis. Here, I deal with both paleoseismological clues from the Monte Marzano Fault System (the structure responsible for the catastrophic, Mw 6.91980 earthquake) and archaeoseismological evidence of settlements founded in its surroundings to cast light on two poorly known earthquakes that occurred at the onset and at the end of the first millennium CE, likely in 62 and in 989 CE. Both should share the same seismogenic structure and the size of the 1980 event (Mw 6.9).
\end{abstract}

Keywords: Irpinia fault; historical earthquakes; archaeoseismology; paleoseismology

\section{Introduction}

As widely demonstrated by several works, the Irpinia fault-which is the popular name of the Monte Marzano Fault System (MMFS, [1])—was responsible in November 1980 for a devastating earthquake (Mw 6.9), which was accompanied by the longest surface faulting ever observed in Italy $(>30 \mathrm{~km})$, at least before the recent central Apennines event (October 2016, Mw 6.6). Early paleoseismological studies [2] claimed that the recurrence time for 1980-like characteristic earthquakes during the Holocene was approximately $2 \mathrm{kyr}$, which is a value clashing with both the frequent destructive seismicity of the area affected by the fault [3] and the high GPS-derived strain rate of the region (at least $2.9 \mathrm{~mm} /$ year [4,5]). This inconsistency was fixed through high-precision topographic leveling run across the compound fault scarp [6], and new paleoseismological trenches and pits opened on different fault segments of the $43 \mathrm{~km}$ long MMFS [7]. Results revealed that most of the destructive earthquakes that hit the upper Ofanto valley in the past two millennia (e.g., events of 1980, Mw 6.9; 1694, Mw 7.0; 1466, Mw 6.3, and many others; as shown in Figure 1) might be ascribed to the MMFS periodical activation, without the necessity of evoking other, unknown faults. 


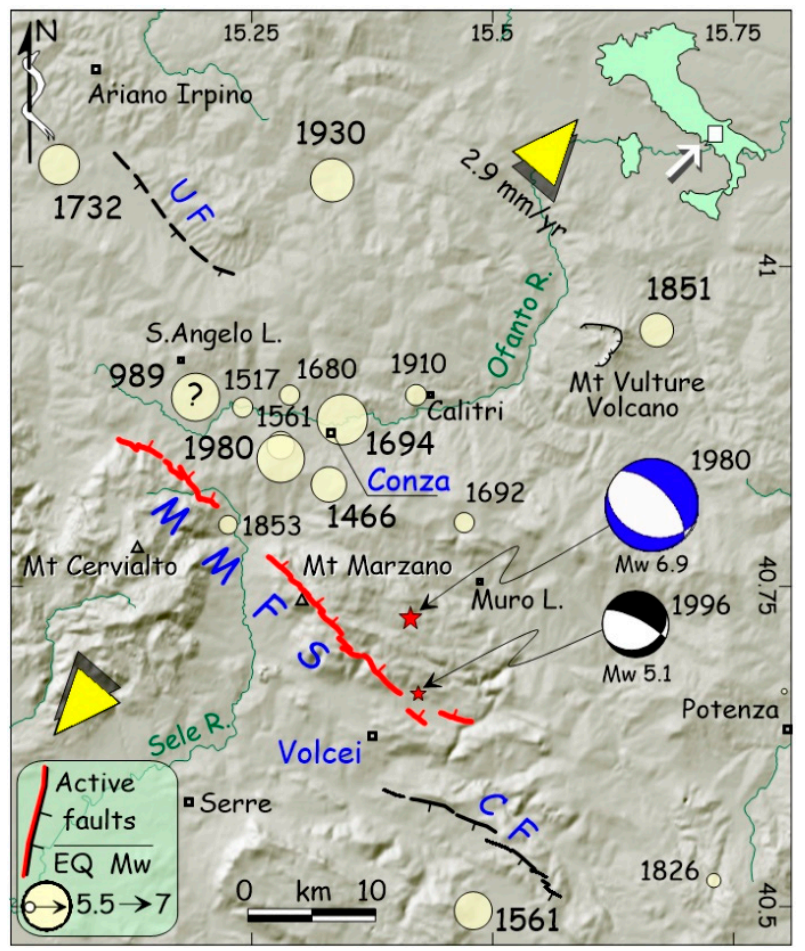

Figure 1. Macroseismic epicenters of $\mathrm{Mw}>5.5$ earthquakes in southern Irpinia (modified from [7]). Notwithstanding possible approximate location, earthquakes cluster mainly in the hanging wall of the Monte Marzano Fault System (MMFS). CF, Caggiano fault; UF, Ufita fault. Stars are the instrumental epicenters of 1980 (Mw 6.9; epicenter from [8]) and 1996 (Mw 5.1) events. Diverging triangles indicate crustal extension, as deduced by GPS analyses published by $[4,5]$.

Macroseismic studies of recent normal faulting earthquakes in Italy showed that the spatial distribution of damage is strongly influenced by rupture directivity effects [9-14], explaining why the same seismogenic source might generate different shaking scenarios time after time. For instance, the 1980 rupture, nucleating from the SE tip of the MMFS toward NW [15], induced the northwestward damage distribution depicted by [16] (Figure 2D). Conversely, in the stronger 1694 earthquake, the rupture nucleated from the NW tip toward SE [7], as proven by the huge damage suffered by many villages located on the eastern side of the highest-intensity data points distribution (from now: HIDD; see Figure 2C).

This paper deals with two little-known earthquakes that were likely generated by the recurring rupture of the Irpinia fault. The first one occurred in the second half of the 1st century CE (Common Era), whereas the second occurred at the end of the 10th century (e.g., $989 \mathrm{CE}$ ). Both have left their destructive imprint in some archaeological settlement of the region, and both are mentioned in a few primary historical sources. Moreover, their signature can be read across the stratigraphy exposed within the paleoseismological trenches opened in the past years along the Irpinia fault or scanning the stepped profile of its compound scarp. By joining historical/epigraphical sources, archaeological evidence, and paleoseismic data, I have tried to provide more reliable seismogenic hypothesis and robust parameters for these events.

Here, I will refer to the MCS scale, which is the Mercalli-Cancani-Sieberg Macroseismic scale $[17,18]$ adopted in all the seismic catalogues and works in Italy. Io and Is are epicentral and site intensity, respectively.

\section{Historical Seismicity of the MMFS Region}

The historical seismicity of the investigated area is among the strongest of the Apennines, both in terms of frequency and of maximum magnitude, with epicenters mainly concentrated in the MMFS 
hanging wall (Figure 1). As observed for the longest normal fault systems dissecting the Apennines [19], the largest events of Irpinia ( $\mathrm{Mw} \geq 6.9$ ) were sourced by the contemporary rupture of the entire MMFS, whereas minor earthquakes occurred on single or grouped segments of this system [7].

Among the latter, the strongest was on January 14, 1466 (Figure 2B), striking the upper Ofanto and Sele Valleys, destroying the town of Conza (Is 9-10 MCS) and causing damage, collapses, and casualties in many other villages in the area, as witnessed by both archaeoseismic indications [20] and contemporary sources [21]. Although we have only 30 intensity points, the 1466 HIDD clearly falls in the hanging wall of the MMFS, roughly mimicking the 1694 and 1980 effects distribution (Figure 2C-D). Nonetheless, as the 1466 event had a lesser destructive impact, it was not sourced by the entire rupture of the MMFS, as happened in the two forthcoming, catastrophic earthquakes. By inverting its HIDD with the Boxer algorithm [22], its equivalent magnitude was rated as Mw 6.3 [7].

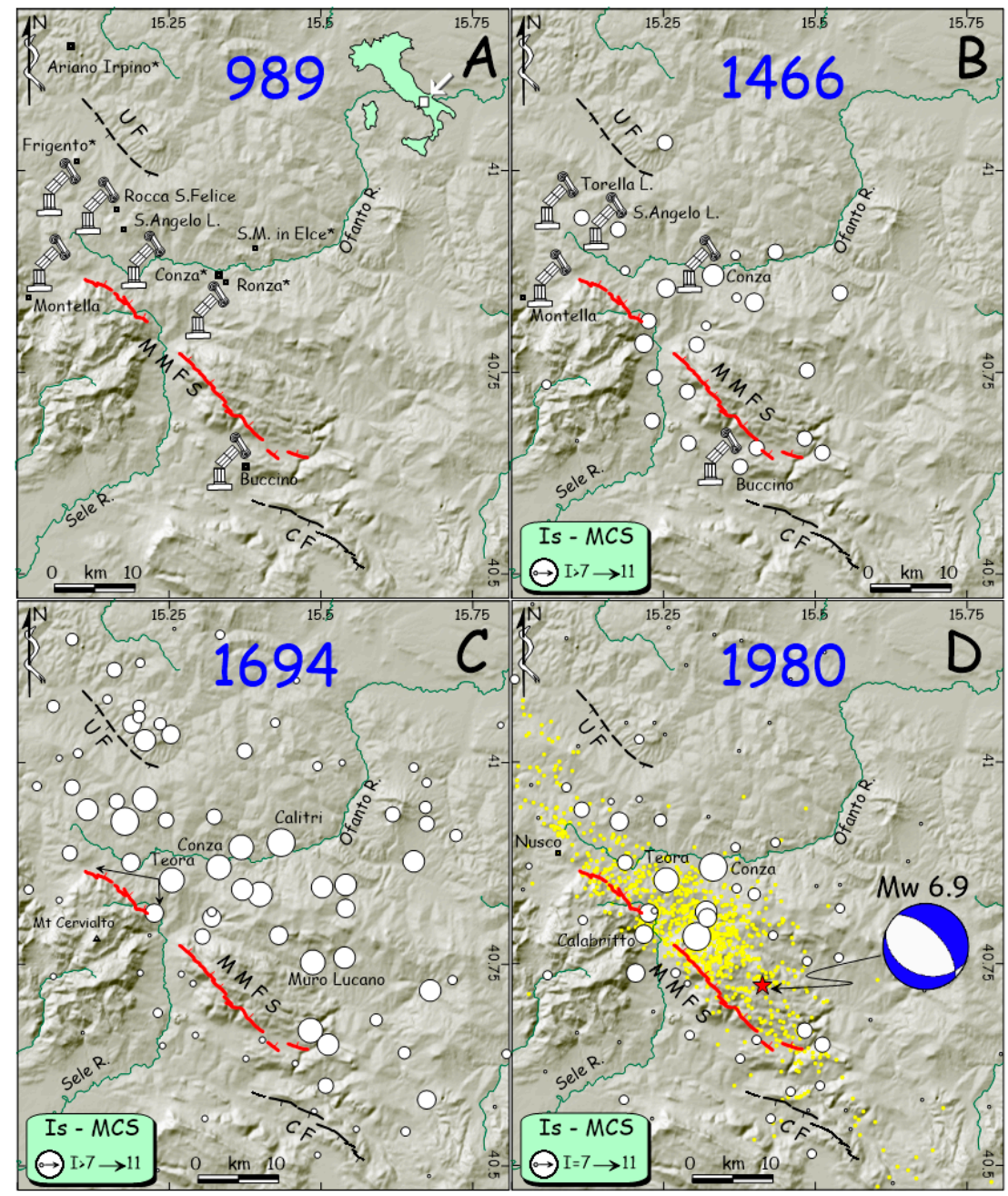

Figure 2. Distribution of effects induced by the 989, 1466, 1694, and 1980 earthquakes (MCS intensities from [7]). (A), 989 event; collapsing columns indicate coeval archaeoseismic evidence (see text). Asterisks, damaged villages quoted by contemporary sources. (B), 1466 event (data from [20,23]. (C), 1694 event; the arrows near Teora indicate the sector of the slope where contemporary accounts describe the opening of a long chasm, which was probably due to surface faulting [7]. (D), 1980 event; yellow circles in the background are 1980 aftershocks. Focal mechanism from [24]. MCS: Mercalli-Cancani-Sieberg Macroseismic scale.

During the 16th century, two damaging earthquakes had again their epicenters in the MMFS hanging wall. On March 29, 1517, the first one caused collapses and victims in Conza, and it was strongly felt from Ariano Irpino to Serre [20]. The second is part of a complex seismic sequence, 
which included three mainshocks occurring between July 30 and August 19, 1561. Castelli et al. [3] located one of these in the upper Ofanto Valley (Figure 1), where it caused heavy damage in several settlements. However, both the 1517 and 1561 events lack conclusive parameters, as their poor or confusing historical descriptions make it difficult to assess robust epicentral coordinates or magnitude.

Starting from the end of the 17th century, the region suffered the strongest seismic period of its long history. Two strong long-term foreshocks in 1680 (9 November) and 1692 (4 March; Figure 1) paved the way to the catastrophic September 8, 1694 earthquake (Mw 7.0), which caused ca. 6000 deaths, razing to the ground (i.e., Is 10-11 MCS) dozens of villages in the upper Ofanto Valley [25]. Even in 1694, the HIDD focuses on the MMFS hanging wall, with an abrupt intensity decrease in the footwall (Figure 2C). Coeval accounts described an impressive ground rupture formed in the Teora mountains, with a length of 10 Neapolitan miles $(18.5 \mathrm{~km})$, suggesting the occurrence of surface faulting along the northern sections of the MMFS, as confirmed by paleoseismological investigations [7].

Leaving aside the catastrophic earthquake of 29 November 1732, which also struck towns located in the upper Ofanto Valley, but with an epicentral area shifted further northwest (Figure 1; Ufita Fault), in 1853 and 1910, the MMFS hanging wall was affected by two other moderate earthquakes. The former (Mw 5.5) caused severe damage in the upper Sele Valley villages (e.g., Caposele and Calabritto [26]), whereas the latter (Mw 5.7) induced collapses and victims mainly in Calitri. The 1853 earthquake can be directly associated with the rupture of a segment of the MMFS, whereas the 1910 was likely sourced by an antithetic fault bounding the hanging wall to the north [7].

At the end, the 23 November 1980 earthquake (Mw 6.9; Io 10) hit the same villages already devastated in 1466 and 1694, destroying 75,000 buildings and severely damaging another 275,000 (Figure 2D). The death toll was 3000, the highest in Italy in the 20th century, after the 1908 (Messina) and 1915 (Fucino) events, with the total destruction of some towns such as Conza (30\% of the victims; Is 11), which was abandoned and rebuilt in another place [16]. The physics of this earthquake have been investigated in several studies [27-30] that reconstructed the complex rupture process along both the main fault (mainshock, and 20-s sub-event) and the antithetic, SW-dipping fault (40-s sub-event). The rupture nucleated at ca. $10 \mathrm{~km}$ in depth [29] and caused impressive surface faulting across the Mount Marzano massif, especially east of the Sele Valley [7,24,31-34].

\section{The Little Known Earthquake of the 1st Century CE}

\subsection{Archaeoseismic Evidence from Volcei}

Robust proofs of multiple destructive events have been found in this ancient town, starting from the late 3rd century BCE [35]. The Roman municipium of Volcei (today Buccino) developed over a settlement existing since the Iron Age close to the Apennine watershed, between the Campania and Basilicata regions (Figure 1). The modern Buccino was heavily damaged (Is 8 MCS) by the 1980 Irpinia earthquake (Mw 6.9), with the successive reconstruction works providing an exceptional opportunity to rediscover the buried remains of the Roman town. As Buccino shares the same ruinous destiny as the other villages struck by the 1980,1694,1561, and 1466 events [3,23], the recognition of widespread, seismically induced effects to the ancient structures was not an unexpected discovery, and it allowed extending our information well behind the memory of the written Modern sources.

During the post-1980 reconstruction works, many indications of ancient collapses, including butti (i.e., stacks of archeological debris), fills, and the leveling of destroyed buildings were found everywhere in the Buccino underground. There was also evidence of restoring and/or rebuilding several Roman houses with architectural elements from previous buildings, such as architraves and epigraphs, which were recycled in the new constructions. Besides all these findings, a coeval epigraph explicitly mentions the restoration made after a collapse due to an earthquake. In the whole, all the indications point to a destructive event falling in the second half of the 1st century $\mathrm{CE}$, as summarized in the forthcoming points (see Figure 3 for sites location), which account mostly for unpublished data 
collected and discussed with A. Lagi, who was formerly responsible for the Salerno Superintendence for the Buccino excavations, and with many other archaeologists who followed one another in the project.
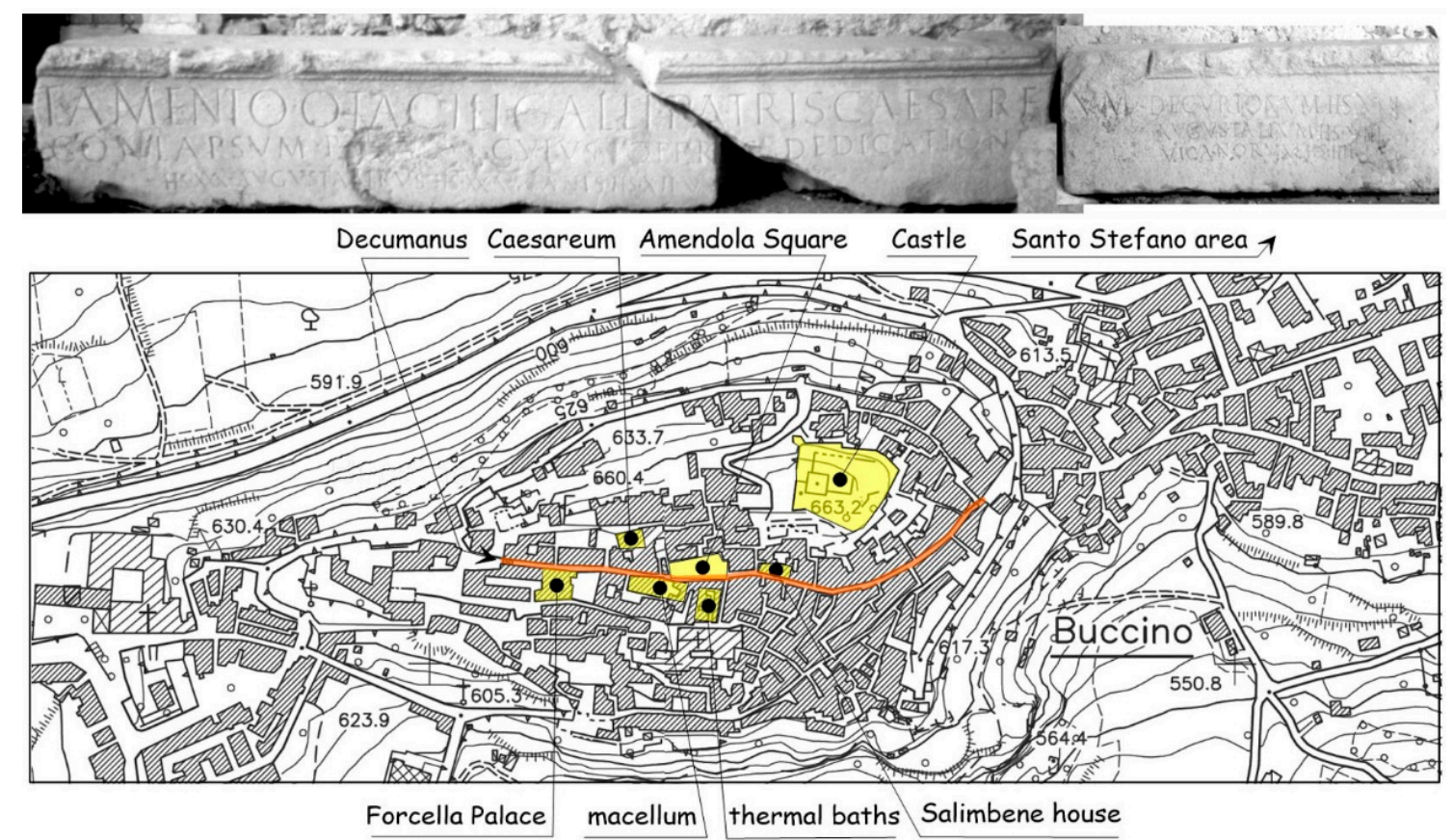

Figure 3. Map of Buccino showing the main archaeological sites attesting the 1st century CE earthquake. Upper panel is the photomosaic of the epigraph of Otacilius Gallus, a far ancestor of mine, attesting the collapse of the Caesareum (photo by P.G.).

\subsubsection{Forcella Palace}

Below this palace, which was built along the Roman Decumanus, the indications consist of a dumping grave containing domestic pottery (lamps and dishes) datable within the first half of the 1st century CE. As no sigillata chiara A pottery (early second half of 1st century CE) was found within the grave, the dumping age must fall at the onset of the second half of the 1st century CE.

\subsubsection{Castle}

Over the southern side of the main 12th century Norman tower (i.e., the donjon, resting over the basement of a Roman temple), the excavations unearthed a broad, rubble fill, which was supported by a wall. The fill was rich in domestic material, bricks, tiles, and limestone masonry blocks, and it was lined upward by a raw concrete pouring. More importantly, it also contains sigillata italica and Africana chiara A pottery, the latter datable to the second half of the 1st century CE (maximum 60-70 CE). At the bottom of the fill, a coin of Emperor Tiberius (23-30 CE) provides a certain post quem term for the rubbles mass, which was thus leveled between the late 1st and the beginning of the 2nd century.

\subsubsection{Sotto San Nicola Street}

In the southeastern slope of Buccino, another dumping grave of both building and domestic rubble has been found. It contains vases and lamps datable within the first half of the 1st century CE (i.e., sigillata italica, pareti sottili pottery), being hence coeval with the castle area fill.

\subsubsection{Amendola Square}

In this place, along the Decumanus, three different dumping graves have been overlaid and sealed with a restoration floor; the infill material contains pottery shards with pareti sottili (early 1st century $\mathrm{CE}$ ). Amongst all the pottery, the archaeologist found the relic of a pot (glilarium or vivarium in doliis) 
containing the skeleton of a dormouse (Glis glis), which was ready to be cooked. At least one of the buildings facing the Decumanus was restored in the 2nd century CE, when also a porticus with four pillars was added to the house. One of the pillars supported an Osco-Latin epigraph, likely recalling the restoration of a nearby vicum venerlum (a brothel?) in the 2nd century (G. Camodeca and A. La Regina, personal communications, 2006). Here, I sampled and dated some charred materials belonging to the wooden structure of the porticus, which was buried by the subsequent collapse of this building during the Early-High Middle Age (see next section). The calibrated age (110-330 CE, 2 $\sigma$ cal.; Table 1) fits the period of general restoration of the town, providing the ante quem term for the collapse.

Table 1. Radiocarbon ages of samples collected in the investigated area (AMS, Accelerator Mass Spectrometry and Radiometric ages by Beta Analytic Inc., Miami, FL, USA). $2 \sigma$ calibration with software Calib 7.1 [36].

\begin{tabular}{cccccccc}
\hline Site & Sample & Laboratory & Dated Material & Dating & d13C & $\begin{array}{c}\text { Measured } \\
\text { Age (BP) }\end{array}$ & 2s cal. 95\% \\
\hline \multirow{2}{*}{ Volcei } & BucAm1c & BETA-175146 & Charred material & AMS & -26.7 & $1810 \pm 40$ & $110-330 \mathrm{AD}$ \\
\cline { 2 - 8 } & BucAm4b & BETA-173042 & Bone Collagene & AMS & -21.1 & $900 \pm 40$ & $1030-1230 \mathrm{AD}$ \\
\hline Compsa & Conz01 & BETA-180232 & Charred material & Radiometric & - & $1240 \pm 70$ & $660-970 \mathrm{AD}$ \\
\hline
\end{tabular}

\subsubsection{Thermal Baths}

Between the 1st and the 2nd century CE, the thermal baths were restored, and their orientation was changed, whereas the floors were completely renewed with different mosaics.

\subsubsection{Macellum}

In the same period (1st-2nd century CE), in the area of the macellum, the two tholoi were dismantled, and the macellum itself was abandoned, whereas its remains were leveled and occupied by new workshops.

\subsubsection{Salimbene House}

Below this house facing the Decumanus, the archaeologists found the remains of a 1st century BCE room ceiling that abruptly collapsed and was successively buried by other structures. By removing the fallen material, it was possible to observe that the incannucciato ceiling collapsed directly over the mortar floor of the room, where it also buried pottery shards of the 1st century CE (Figure 4). This clearly means that the room was in use when the collapse happened.

\subsubsection{Caesareum Temple}

Here, in the same period (1st century CE), an opus caementicium cistern was built with the aim of supporting the damaged retaining wall of the temple. The severe damage suffered by this temple is also testified by the epigraph of Otacilius Gallus that will be hereafter described.

In the whole, the archaeological data evidence a general, abrupt discontinuity within the urban texture of the Roman Volcei, followed by a reconstruction phase focused between the 1st and 2nd century CE. The great abundance of domestic pottery, tiles, bricks, and stones in the dumping graves, summed to the existence of leveled rubble fills, are the proof of contemporary, extensive building collapses in the town. Moreover, the discovery of the pot with the dormouse, ready to be cooked when it was buried under the rubble, and the Otacilius' epigraph, attesting the collapse of the Caesareum, are conclusive proofs concerning the occurrence of this event. Last but not least, a further clue evocating the tragedy caused by this earthquake comes from the funerary monument of Gresia Tertia, which is located only $10 \mathrm{~km} \mathrm{SE}$ to Volcei. Here, archaeological investigations unearthed an epigraph datable within the 1st century CE, where an infelix mater (a desperate mother) cries over the death of her family, 
namely all the four sons and the father. Even if the cause is not declared, the simultaneous decease of five persons in the same family could really be related to the collapse of their house.

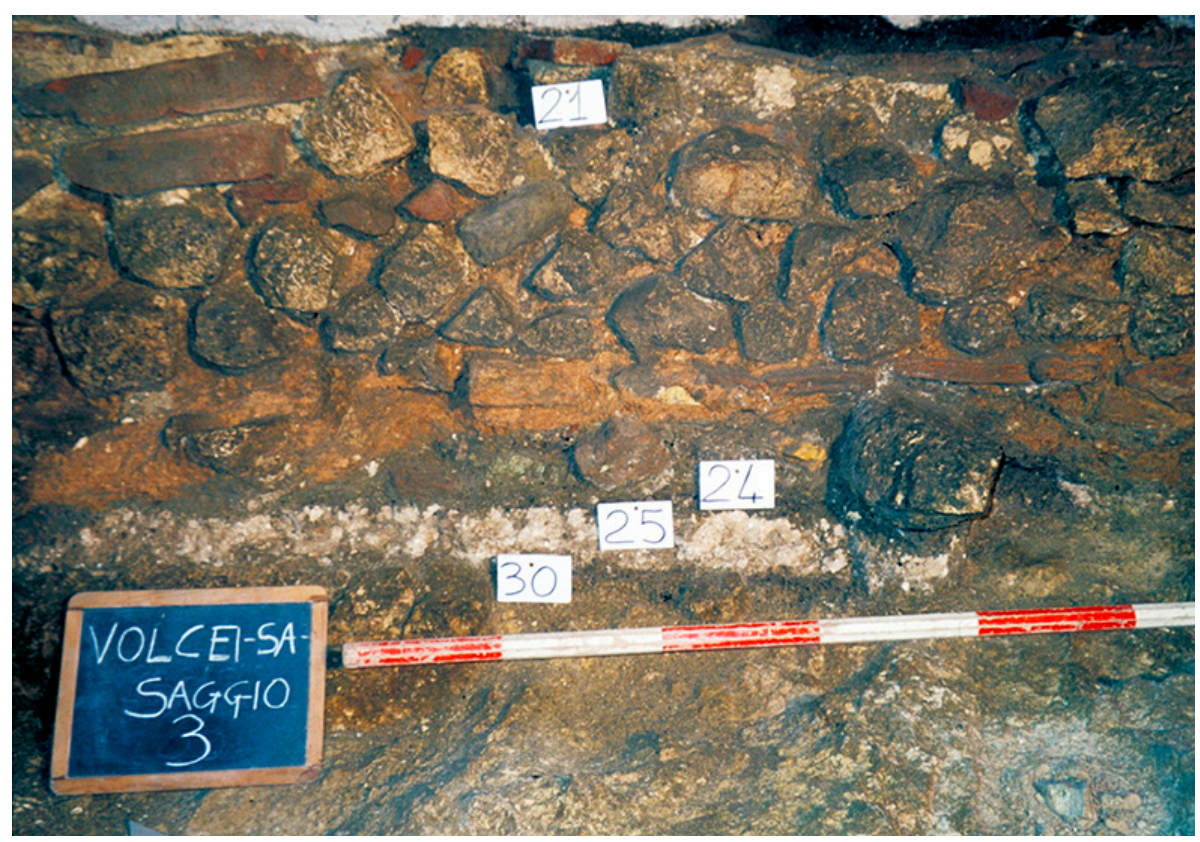

Figure 4. Simultaneous collapse of the incannucciato ceiling (unit 24) and of the plaster (25) over the mortar floor (30) of the inhabited room. Unit 21 is instead the foundation of a medieval wall that was carved within the Roman rubble. For the record, this medieval wall collapsed due to a further earthquake, and its relics were found inside an adjacent room (photo by P.G.).

\subsection{Archaeoseismic Evidence from Compsa}

The municipium of Compsa (today Conza, Figure 1), similar to the nearby Volcei, starting from the 1st century BCE, flourished throughout the whole Imperial period, surviving to the Late Antiquity decline without dramatic urbanistic breaks [35]. However, despite the monumental buildings of the 1st century BCE being renewed under Emperor Augustus at the beginning of the 1st century CE [37,38], the archaeologists have found sparse indications of further works made just after a little interval, consisting of the reworking of the Capitolium, its podium, and its staircase. Moreover, they noticed the restoration of other new buildings surrounding the forum, with the demolition of structures built only a few years before, as the columns of the porticus or the wall of the sacellum (F. Soriano, personal communications, 2020). Thus, whereas the architectural improvement of the monumental buildings during the Augustus period is typical in almost all the Roman towns of the time, the rebuilding of the same structure only a few years after might suggest the occurrence of a destructive event, such as an earthquake. In this case, the archaeologist placed it just after the first half of the 1st century CE.

\subsection{Paleoseismic Evidence from MMFS Trenching}

Besides the archaeological proofs of this earthquake, there exists also geological evidence of its occurrence and size. As aforementioned, the authors of [6,7] performed both high-precision topographic leveling across the MMFS scarp and new paleoseismic trenches across different segments of the master fault. About 60 topographic profiles revealed the presence of at least 4 clusters of retreated scarp edges (e.g., up-slope: migrating inflection points: [6]), representing as many surface faulting events (Figure 5). These match 4 paleoseismic episodes recognized within trenches, the age of which was successively defined by the AMS dating of numerous key samples collected there. 


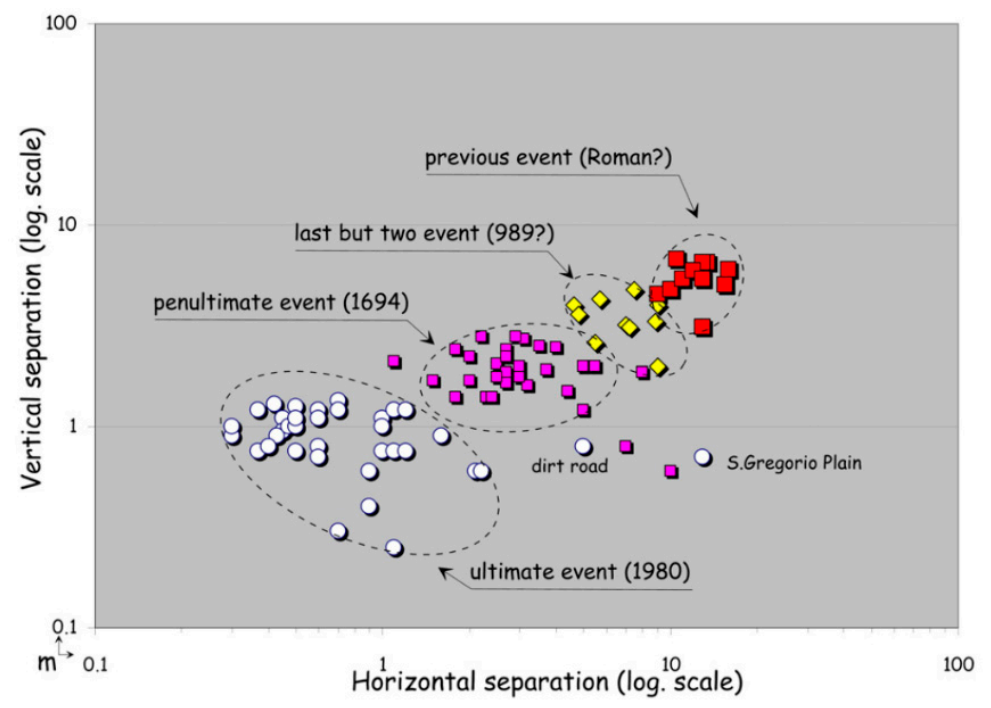

Figure 5. Horizontal versus vertical separation values measured through high-precision topographic profiles across the compound fault scarp of Monte Marzano faults (vertical values are cumulated). The different clusters provide evidence for at least four major surface-faulting events. The older the rupture, the higher the vertical and horizontal separation (mod. from [6]).

In detail, the fourth cluster was dated in the trenches T1 and T2 of [7]. These excavations (Figure 6) provided robust evidence of slope debris offset that occurred just before 80-310 CE, which is a time matching the oldest event recognized also in T3, where this was dated between 540-390 BCE and 540-650 CE. The event also fits event 2 in [2], which occurred between 620 and 230 CE. Considering all the above, the preferred age of [7] was bracketed within the early Imperial Period (1st-2nd century CE).

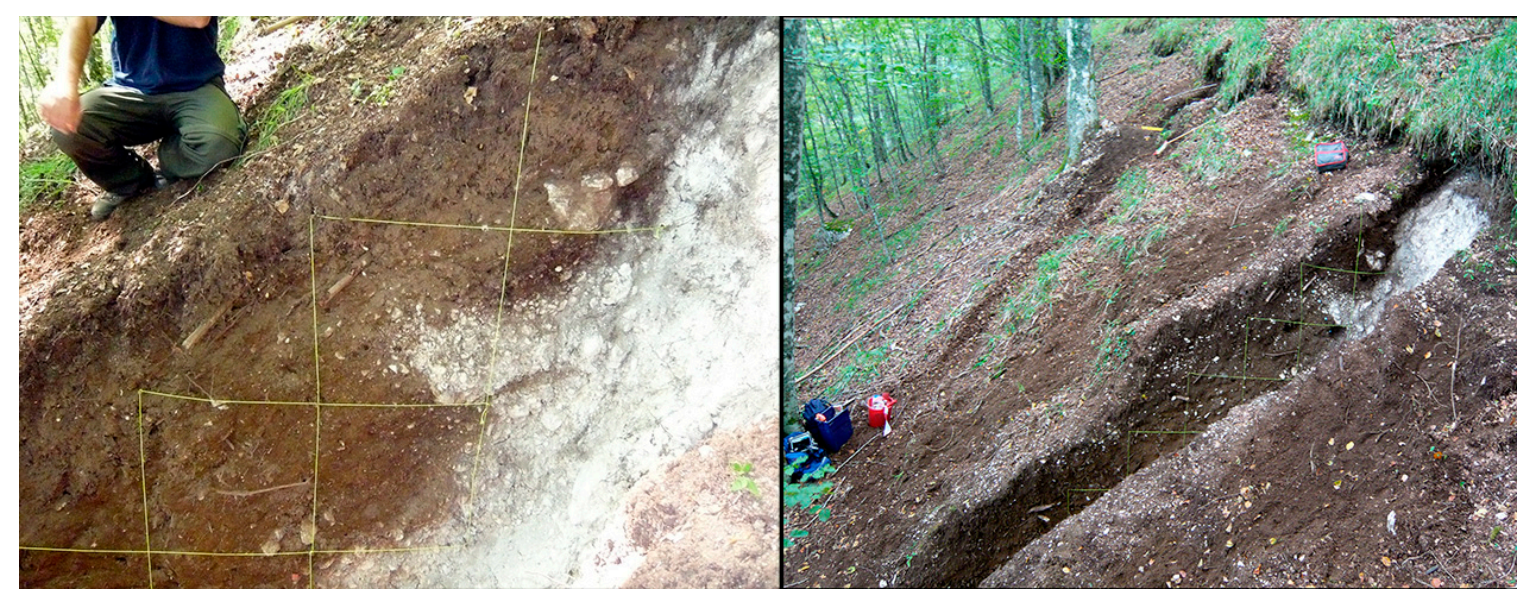

Figure 6. View of trenches T1-T2 during the excavation along the $>30^{\circ}$ dipping slope of Monte Valva-Marzano (summer 2010). Note, in the right panel, the 1980 surface offset, still visible after 30 years. The blow-up of T2 (left panel) focuses on the tectonic wedges formed in the 989 and 1694 surface faulting (see details in [7]) (photos by P.G.).

\subsection{Historical Sources}

In a strict sense, historical accounts concerning the effects of this earthquake in Irpinia do not exist. Leaving aside the intriguing epigraph of Gresia Tertia and the ambiguous Osco-Latin epigraph in Amendola square, the only certain information is provided by the epigraph of Otacilius Gallus. This was carved on an architrave (Figure 3), and it recalls the collapse of the Caesareum, which is a temple built only one century before, around 50-60 BCE. The text is: 
OTACILIVS EX TESTAMENTO OTACILI GALLI PATRIS CAESAREVM/[TERRAE MOTV] CONLAPSVM P(ecVnia) [S(Va) R(estitVit)]. CVIVS OPER[IS] DEDICATIONE/[DEDIT DECVRIONIBVS] (sestertios) XXX, AVGVSTA[L]IBVS (sestertios) XX, VICANIS (sestertios) XII, VX[ORIBVS]/ DECVRIONVM (sestertios) XVI, AVGVSTALIVM (sestertios) VIII, VICANORVM (sestertios) IIII

which roughly means: "Otacilius, according to the will of his father, rebuilt by its own the Cesareum which was destroyed by an earthquake ... etc.". If the integration of the missing text (square-brackets: [39]) is correct, the Caesareum was destroyed by an earthquake that occurred before the end of the 1st century CE, and it was then restored by Otacilius in the 2nd century (G. Camodeca, personal communication, 2006).

\section{The 989 CE Earthquake}

\subsection{Historical Sources}

This is the first earthquake explicitly quoted in the Irpinia area, and it was already reported by the first Italian editors of seismic catalogues, as Giannozzo Manetti, Colanello Pacca, and Marcello Bonito [40-42]. Manetti mentions the collapse of several buildings in Benevento and Capua, as in Ariano, Ronza, and Conza, where many people and the Bishop died. In turn, Pacca places the earthquake in 982 in the Naples Kingdom, describing the effects in Benevento, Capua, Ariano, Frigento, Conza, and Ronza. Bonito places it in 989, reporting texts and sources that he painstakingly collected. In short, the primary sources to which these three authors refer are the Annales Beneventani [43], the Chronica Monasterii Casinensis [44], and the Chronicon of Romualdo Guarna [45]. The exact year of the earthquake has been fixed to 989 by [46], who cross-checked other certain historical episodes to which the event can be chronologically referred. Nevertheless, on the basis of the only historical descriptions, its epicentral parameters were not univocally defined. The most interesting information derives from Leone Ostiense, the author of [44], who was writing in the Montecassino Monastery and likely used first-hand sources, which are lost today. In few words, he informs us that the earthquake struck Vipera (this toponym still exists in the Istituto Geografico Militare maps near Benevento) and Benevento, where 150 died and 15 towers collapsed, whereas in Capua, many houses fell down, and the bells rung. Ariano Irpino and Frigento were almost completely destroyed, as was Conza, where many inhabitants died together with the Bishop, while Ronza (a settlement close to Conza) was totally razed to the ground. Leaving aside the inconsistent news from the very far town of Capua (where bell towers just ring while houses are collapsing), on the basis of all the news, [20] assigned Is 10-11 MCS to Ronza, 10 MCS to Conza, and 9-10 MCS to Ariano and Frigento, while in Benevento, the most important and populated town of the region, the number of casualties may suggest at least an Is 8-9 MCS intensity.

\subsection{Archaeoseismic Evidence from Compsa}

Here, the archaeological excavation performed after the 1980 earthquake by the former Superintendency of Salerno, Avellino, and Benevento unearthed vast areas of the Roman and Medieval town. As a matter of facts, buildings and tombs of Byzantine age (6th century) before, and Langobardic (7th century) then, occupied the Forum area, always resting in phase with the Roman town levels. A proto-cathedral was also built over the Roman Capitolium, with a staircase connecting the church to the forum pavement [47-49]. The archaeoseismic survey conducted with the archaeologists during the excavation in 2003 allowed collecting indications of a strong break in the Early Middle Age history of Compsa, which was namely between the 10th and 11th century. After this break, for the first time after its foundation, the town was not rebuilt, respecting the inherited urbanistic Roman texture. An extended level of rubble, containing pottery shards and coins of the 10th century, buried the limestone slabs of the Forum and all its inscriptions [50]. The first cathedral, erected on the Capitolium, collapsed and was later rebuilt close to the Forum, although it was rotated with respect to the axes of the Roman-Early Middle Age town. The new apse occupied a part of the previous Forum, covering the leveled strata of destruction. Here, I made a radiocarbon dating of a huge charred fragment sampled 


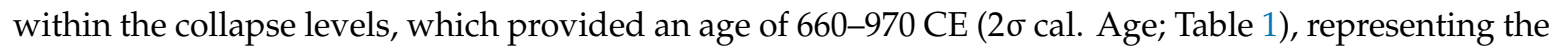
post quem term of the earthquake destruction (Figure 7). Unfortunately, this new basilica, consecrated in 1122 [51], will be soon destroyed by the forthcoming 1466 earthquake, and then again in 1694, 1732, and definitely 1980 [20].

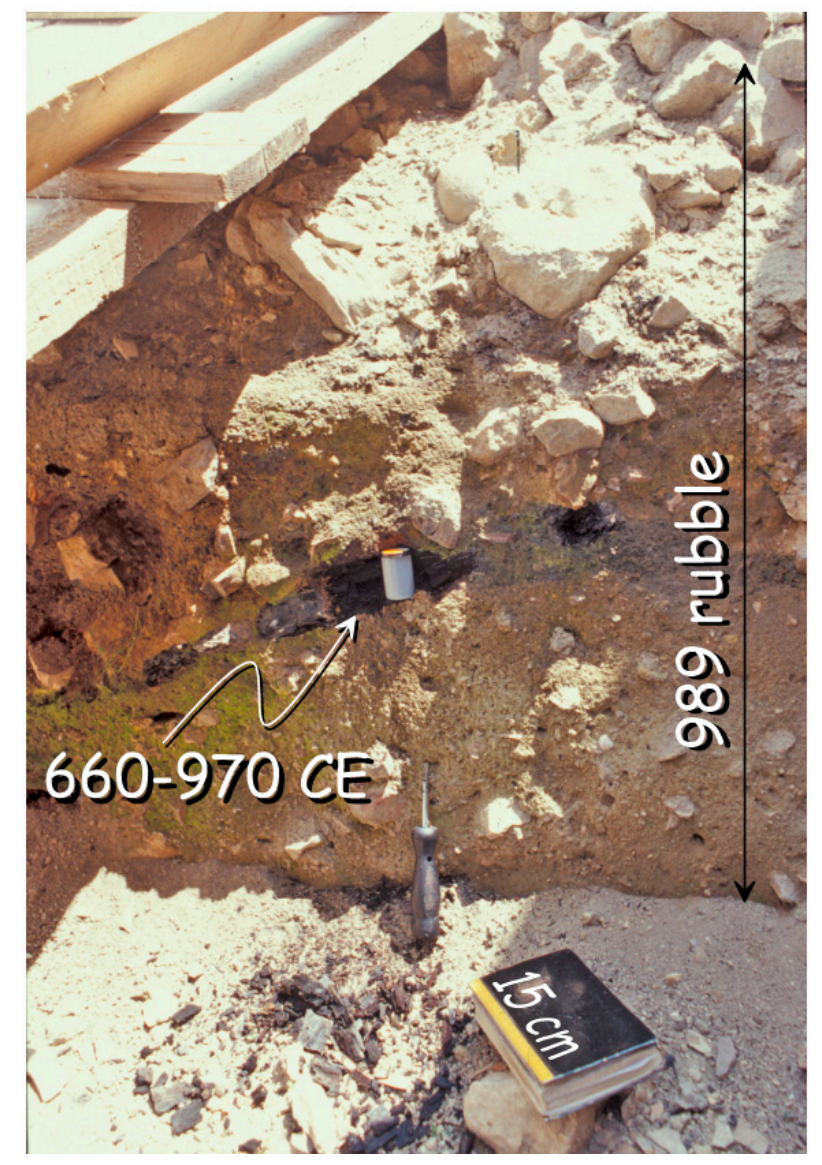

Figure 7. Rubble and abandonment layers excavated in the Forum area of Compsa, over the limestone slabs (below the booklet). The radiocarbon dating of a charred wood (660-970 CE; $2 \sigma$ cal. age) provided the post quem term for the destruction of the Early Middle Age town in the 989 earthquake (photo by P.G.).

\subsection{Archaeoseismic Evidence in Volcei}

Here, the evidence of the 989 event is represented by the synchronous and total collapse of the buildings excavated below Amendola Square and in other neighboring insulae. Moreover, it is witnessed by the general abandonment of the surviving Late Antiquity buildings, which were still inhabited during the Langobardic period, and by the new urban topography that, as in Conza, drifts apart from the Roman imprint, assuming a concentric path around the new castle. Actually, in Volcei, it is difficult to provide univocal age brackets for this earthquake, mainly because of the paucity of the Early Middle Age pottery. However, archaeoseismic clues are constrained between the 7 th-8th and the 12th century, even if I cannot exclude the occurrence of multiple events within this time span. The crude set of indications can be summarized as follows (Figure 3 for location).

\subsubsection{Amendola Square}

The excavations have revealed the synchronous collapse of all the buildings surviving since the Late Roman times. Below the rubble, it has been possible to read the history of these houses, with the different redistricting of each room during times, the wall restorations, the floors overlapping, and the 
doorstep reutilization. The collapse affected all the masonry walls, the pillars of the porticus, and the roofs, which have been found all directly overlaying the floors (Figure 8). This catastrophic collapse also definitely buried the Decumanus, which was still in use and well maintained at least during the 7 th century, as testified by the materials found in the ditches. At first glance, the collapse also killed a small sheep, which was hit and buried by the rubble on the road basoli (see the arrow in Figure 8). I sampled and obtained an AMS collagen dating of 1034-1214 AD (2 $\sigma$ cal.) from the sheep bones. Inside the porticated building, beside the collapse of the wall plasters of the incannucciato ceiling, tiles, and masonry, it was possible to observe some walls and the four bricks/pillars that fell away from the road, burying bande rosse pottery (used all along the Early Middle Age).

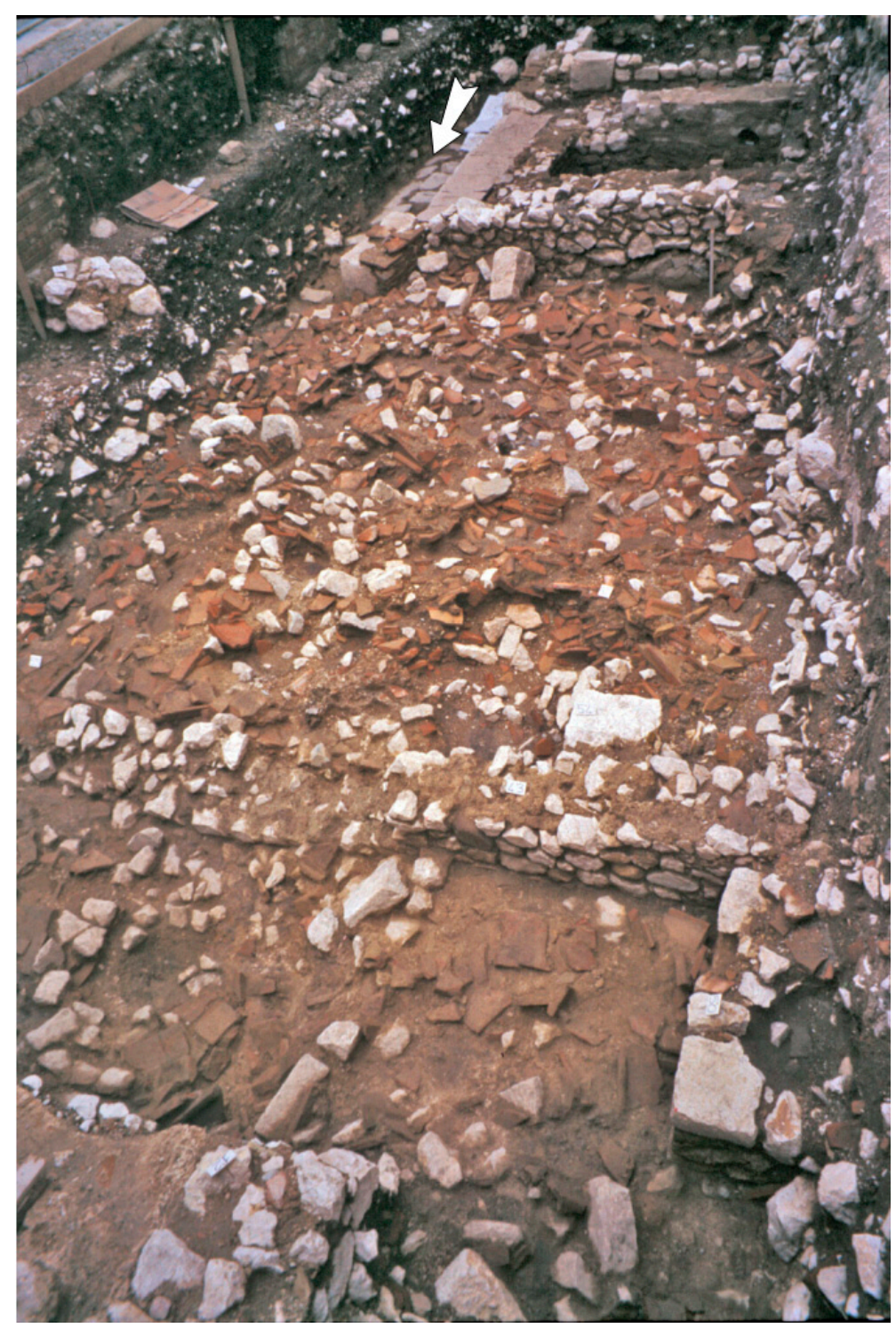

Figure 8. Amendola Square insula. View looking west of the amazing, total, and simultaneous collapse of the porticated house over the Decumanus before the removal of the roof (reddish material). The arrow points to the limestone basoli, where the sheep was found (photo by P.G.).

\subsubsection{Salimbene House}

An Early Middle Age cobble wall was founded inside the fill burying the Roman buildings (Figure 4). The pottery shards inside the foundation trench are the same as in Amendola Square, i.e., it contains bande rosse pottery. Therefore, this wall-which successively collapsed over a nearby 
room-might suggest the onset of the reconstruction of the Early Middle Age Buccino after and over the earthquake rubble.

\subsection{Other Settlements}

In order to enrich the framework of effects distribution related to this earthquake, I collected further indications concerning damage to ancient buildings (see Figure 2A) with the assistance of M. Rotili (Naples University; personal Communication, 2002).

\subsubsection{Frigento}

Here, [52] described the burying of the right apse of the Langobardic Mother Church, which collapsed and was successively leveled prior to the early 11th century. The rebuilding of the church is dated between the 11th and 12th century, when the new structures were founded over the walls of the collapsed church, or directly over the infill of its ruins.

\subsubsection{Montella}

In the Angevin Park, [53] found the 13th-14th century boundary wall built over the leveling of the collapsed 9th century wall. In turn, other remains of the 9th century wall were still laying outside the newer wall, burying tombs of the 7th-8th century.

\subsubsection{Rocca San Felice}

Here, [53] hypothesizes the destruction and successive reconstruction of the 7th-8th fortified structure because of the 989 earthquake. This is also attested by the 10th-12th century donjon that was built over the leveling of the Langobardic structures.

\subsubsection{Sant'Angelo dei Lombardi}

The same author [53] claims for the 989 earthquake shaking in order to explain the destruction of the Langobardic fortified settlement, which was rebuilt in the 11th-12th century. As well as the restoration and reinforcing of the previous damaged wall, the Norman donjon was erected over the leveling of the Langobardic structures, as in Rocca San Felice. Moreover, it is worth noting that the right apse of the 11th-12th century cathedral was founded over the leveling of the old, collapsed boundary wall.

\subsection{Paleoseismic Evidence from MMFS Trenching}

In the trenches opened by [7] and along the fault-scarp profiles discussed in [6], between the signatures of the 1st century CE and the 1694 earthquakes, these authors have found the clear evidence of a Middle Age surface faulting (Figure 5). In trenches T1-T2 (Figure 6), they placed it contemporary or slightly after 720-970 CE (age of the infilling colluvium at the bottom of a coseismic tectonic wedge), and well before 1190-1270 CE and 1260-1390 CE (age of the units sealing offset levels). The same event was also found in T8, where it occurred after 685-892 CE.

\section{Discussion and Conclusions}

An unexpected and tragic event, such as the Mw 6.9, 1980 Irpinia earthquake, allowed rediscovering the buried relics of the Roman municipium of Volcei (Buccino) and of Compsa (Conza). The amazing discovery is that below the ruins of the 1980 earthquake, the archaeologists have found a palimpsest of constructions/collapses/reconstructions attributable to as many seismic events that, each time, have partly allowed the freezing of the buildings history below their own rubble. Although sometimes, the unraveling of this tangled skein of construction/destruction events is a very hard task, with the guide and help of the archaeologists, it has been possible to collect several indications from different sectors of the towns that suggest the occurrence of different earthquakes striking Volcei/Buccino and 
Compsa/Conza in the past, and in particular, one in the 1st century CE and one in the 10th century, i.e., the 989 earthquake.

1st century CE earthquake-In Volcei, many archaeological evidence indicate a strong, destructive event that occurred in the second half of the 1st century $\mathrm{AD}$, as constrained well by the age of the huge amount of pottery materials found by the archaeologists, which is supported also by the AMS dating of wooden structures. Conversely, in Compsa, this event was not clearly identified due to the lack of the Roman stratigraphy, which was mostly removed by the early post- 1980 works. However, here archaeologists agree that the ${ }^{1}$ st century BCE Forum was newly rebuilt in the early 1st century CE $[39,50]$, whereas it was again restored and reworked only a few years after (F. Soriano, personal communication, 2020), i.e., contemporary to the well documented Volcei reconstruction. This earthquake, which is unknown to the seismological compilations in this region, can be related to the one found by means of paleoseismological analyses across the Mount Marzano Fault System [7], where it was dated a time before 80-310 CE. Alongside the archaeoseismic and paleoseismic indications, this event is recorded by an epigraph that, although incomplete, clearly mentions the collapse of the Caesareum of Volcei. Given the lack of classical literary sources for the Irpinia area, a very speculative hypothesis concerning its age may be suggested by the concurrence of the so-called Pompei earthquake in $62 \mathrm{CE}$. Bearing in mind that the strongest earthquakes sourced by the MMFS, as well as by many others Apennines faults [54], always induced high-intensity effects in the surrounding of Naples (e.g., Is 7 MCS in both 1694 and 1980 events, with isolated collapses and casualties; see [55]), it could be possible that the damage reported by the historical sources in ancient Pompei, Naples, Ercolano, and Nocera might represent the far-field effects of the same earthquake that razed to the ground Compsa and Volcei. It is worth remembering that Seneca in the Naturales quaestiones [56], besides describing the effects in the aforementioned towns, also stresses that the earthquake "Campaniam ... magna strage vastavi" (destroyed the Region Campania with many casualties) and "non desiit enim assidue tremere Campania" (Campania continued trembling), likely alluding that damage was spread over a vast area. If this were true, according to the theory of elastic stress transfer, one could also tentatively hypothesize that this Apennine earthquake was the one that triggered the forthcoming 79 CE Vesuvius eruption. This is suggested by some of the case histories presented and discussed in [57], although more robust hypotheses were discussed in [58].

989 CE earthquake-Differently from the 1st century earthquake, Compsa was explicitly quoted among the towns destroyed by the 989 event. In turn, even in this case, its archaeological evidence is less detailed than in Volcei, as most of the first excavations after the 1980 earthquake were made without a systematic description, documentation, and collection of archaeological materials. However, the available data undoubtedly suggest that an earthquake occurred at the end of the 10th century (i.e., post 660-970 CE, before 1122) causing the almost total destruction of Compsa, which was successively abandoned and then slowly rebuilt and repopulated. Besides Compsa, other settlements of the region show archaeoseismic evidence of contemporary destruction and reconstruction, such as Frigento (also mentioned by the historical sources), Montella, Rocca San Felice, and Sant'Angelo dei Lombardi, which were all heavily struck by the 1980 event as well.

In Volcei, there are many indications of coeval destruction around the end of the 10th century, although the univocal dating of collapses is problematic. Indeed, whereas the pottery shards involved and buried by the collapses predate the onset of the second millennium, the AMS dating of the sheep buried under the rubble would indicate a slightly later age. Considering the uncertainty that often arises from collagen dating, the simplest hypothesis is that an event occurred between the uppermost and lowermost boundary of the two terms, i.e., around $1000 \mathrm{AD}$, a time fitting the October 25, 989 earthquake. However, this framework is complicated by the presence of a 16th century historical source who mentions that an earthquake occurred at the times of Pope Callistus II (1119-1124), the destructive effects of which were still visible in Buccino in the "horti...nella parrocchia de S Maria Sollitta..." ( $\ldots$ in the gardens of St Mary Sollitta church [59]). The period of Pope Callistus fully matches the AMS age of the sheep squashed under the rubble, although it is not consistent with the time span 
suggested by the pottery. Nevertheless, considering the high frequency of earthquakes occurrence in this region $[3,20]$, we cannot exclude that more than one event hit Buccino just before and after 1000 $\mathrm{CE}$, cumulating damage and favoring the collapse of the highly vulnerable Middle Age buildings. As a matter of fact, in one of the houses below Amendola Square, the archaeologists unearthed a small lime furnace that was operating at the time of the collapse. The furnace overlays a thin abandonment level on the floor, suggesting that men were working inside an uninhabited house [33]. Thus, an attractive hypothesis, which makes no claims to being conclusive, is that while works were in progress for repairing the damage of the 989 earthquake, another event caused the complete collapse of the buildings around $1120 \mathrm{CE}$ and the definitive burying of the ancient Decumanus.

As well as in the case of the Roman event, paleoseismic results along the MMFS support the presence of a Middle Age surface faulting. This was dated as contemporary or slightly after 720-970 CE, and well before 1190-1270 CE. Last but not least, the rupture of the MMFS in this period matches the distribution of the settlements destroyed by the 989 earthquake, which all fall in the hanging wall or in the surroundings of the Irpinia fault.

As a concluding remark, I would like to stress that the results summarized in this short review represent some intriguing case histories in the investigation of ancient earthquakes. The concurrent presence of historical sources, archaeoseismic indications, and paleoseismic evidence of the same earthquake have been rarely observed not just in Italy, but also worldwide. The contribution of each discipline strengthens the parametrization of the earthquake, both in terms of age, location, and energy released. The probable association with the seismogenic source of the 1980 earthquake suggests that both the 1st century CE and $989 \mathrm{CE}$ events had a comparable magnitude (Mw 6.9), whereas the age brackets provided by the archaeoseismic and paleoseismic results suggest the challenging hypothesis that the older event might be the one that in $62 \mathrm{CE}$ damaged Pompei, anticipating and, dubiously triggering, the famous Vesuvius eruption in $79 \mathrm{CE}$.

Funding: This research received no external funding.

Acknowledgments: I am grateful to all the archaeologists who shared with me all their findings, discussing with me the hypotheses presented in this paper. In particular, I am indebted to Adele Lagi, who spent a lot of time explaining me the secrets of all the stones of Volcei. I wish to thank also Gabriella Colucci Pescatori, Enzo di Giovanni, Pierfrancesco Talamo, Fiammetta Soriano and Marcello Rotili.

Conflicts of Interest: The author declares no conflict of interest.

\section{References}

1. Galli, P.; Galadini, F.; Pantosti, D. Twenty years of paleoseismology in Italy. Earth-Sci. Rev. 2008, 88, 89-117. [CrossRef]

2. Pantosti, D.; Schwartz, D.P.; Valensise, G. Paleoseismology along the 1980 surface rupture of the Irpinia Fault: Implications for earthquake recurrence in the southern Apennines, Italy. J. Geophys. Res. Space Phys. 1993, 98, 6561-6577. [CrossRef]

3. Castelli, V.; Galli, P.; Camassi, R.; Caracciolo, C. The 1561 Earthquake(s) in Southern Italy: New Insights into a Complex Seismic Sequence. J. Earthq. Eng. 2008, 12, 1054-1077. [CrossRef]

4. Palano, M.; Cannavo, F.; Ferranti, L.; Mattia, M.; Mazzella, M. Strain and stress fields in the Southern Apennines (Italy) constrained by geodetic, seismological and borehole data. Geophys. J. Int. 2011, 187, 1270-1282. [CrossRef]

5. D'Agostino, N. Complete seismic release of tectonic strain and earthquake recurrence in the Apennines (Italy). Geophys. Res. Lett. 2014, 41, 1155-1162. [CrossRef]

6. Galli, P.; Peronace, E.; Quadrio, B.; Esposito, G. Earthquake fingerprints along fault scarps: A case study of the Irpinia 1980 earthquake fault (southern Apennines). Geomorphology 2014, 206, 97-106. [CrossRef]

7. Galli, P.; Peronace, E. New paleoseismic data from the Irpinia Fault. A different seismogenic perspective for southern Apennines (Italy). Earth-Sci. Rev. 2014, 136, 175-201. [CrossRef]

8. Westaway, R. Seismic moment summation for historical earthquakes in Italy: Tectonic implications. J. Geophys. Res. Space Phys. 1992, 97, 15437. [CrossRef] 
9. Berardi, R.; Contri, P.; Galli, P.; Mendez, A.; Pacor, F. Modellazione degli effetti di amplificazione locale nelle città di Avezzano, Ortucchio e Sora. In 13 Gennaio del 1915. Il Terremoto Nella Marsica; Castenetto, S., Galadini, F., Eds.; Servizio Sismico Nazionale, Istituto Poligrafico dello Stato: Rome, Italy, 1999; pp. 349-371.

10. Ameri, G.; Bindi, D.; Pacor, F.; Galadini, F. The 2009 April 6, Mw 6.3, L'Aquila (central Italy) earthquake: Finite-fault effects on intensity data. Geophys. J. Int. 2011, 186, 837-851. [CrossRef]

11. Galli, P.; Bosi, V.; Galadini, F.; Meghraoui, M.; Messina, P.; Basili, R.; Moro, M.; Sposato, A. Fratturazione superficiale connessa ai terremoti umbro-marchigiani del settembre-ottobre 1997. II Quaternario 1997, 10, 255-262.

12. Galli, P.; Camassi, R.; Azzaro, R.; Bernardini, F.; Castenetto, S.; Molin, D.; Tertulliani, A. Il terremoto aquilano del 6 aprile 2009: Rilievo macrosismico, effetti di superficie ed implicazioni sismotettoniche. Il Quaternario 2009, 22, 235-246.

13. Galli, P.; Peronace, E.; Bramerini, F.; Castenetto, S.; Naso, G.; Cassone, F.; Pallone, F. The MCS intensity distribution of the devastating 24 August 2016 earthquake in central Italy (Mw 6.2). Ann. Geophys. 2016, $59,13$.

14. Galli, P.; Castenetto, S.; Peronace, E. The Macroseismic Intensity Distribution of the 30 October 2016 Earthquake in Central Italy (Mw 6.6): Seismotectonic Implications. Tectonics 2017, 36, 2179-2191. [CrossRef]

15. Cocco, M.; Pacor, F. The rupture process of the 1980 Irpinia, Italy, earthquake from the inversion of strong motion waveforms. Tectonophysics 1993, 218, 157-177. [CrossRef]

16. Postpischl, D. Atlas of Isoseismal Maps of Italian Earthquakes. Quad. Ric. Sci. 1985, 114, 2 A.

17. Sieberg, A. Geologie der Erdbeben. Handb. Geophys. 1930, 2, 552-554.

18. Molin, D. Rilievo Macrosismico in Emergenza. Rapporto Interno del Dipartimento della Protezione Civile, Ufficio Valutazione, Prevenzione e Mitigazione del Rischio Sismico. Unpublished work, 2009; 13p.

19. Galli, P. Recurrence times of central-southern Apennine faults (Italy): Hints from palaeoseismology. Terra Nova 2020. [CrossRef]

20. Galli, P. La storia sismica di Conza. In Conza Storia Arte Fede; Ricciardi, E., Ed.; Grafiche Pannisco: Calitri, Italy, 2010; pp. 23-70.

21. Figliuolo, B.; Marturano, A. Il terremoto del 1466. Rass. Stor. Salernitana 1996, 25, 93-109.

22. Gasperini, P.; Vannucci, G.; Tripone, D.; Boschi, E. The Location and Sizing of Historical Earthquakes Using the Attenuation of Macroseismic Intensity with Distance. Bull. Seism. Soc. Am. 2010, 100, 2035-2066. [CrossRef]

23. Galli, P.; Bosi, V.; Piscitelli, S.; Giocoli, A.; Scionti, V. Late Holocene earthquakes in southern Apennine: Paleoseismology of the Caggiano fault. Acta Diabetol. 2006, 95, 855-870. [CrossRef]

24. Westaway, R.; Jackson, J. The earthquake of 1980 November 23 in Campania-Basilicata (southern Italy). Geophys. J. Int. 1987, 90, 375-443. [CrossRef]

25. Serva, L. Il terremoto del 1694 in Irpinia e Basilicata. In Contributo alla Caratterizzazione della Sismicità del Terremoto Italiano; CNEN: Udine, Italy, 1981; 67p.

26. Porfido, S.; Esposito, E.; Luongo, G.; Marturano, A. I terremoti del XIX secolo dell'Appennino Campano-Lucano. Mem. Soc. Geol. Ital. 1988, 41, 1105-1116.

27. Bernard, P.; Zollo, A. The Irpinia (Italy) 1980 earthquake: Detailed analysis of a complex normal faulting. J. Geophys. Res. Space Phys. 1989, 94, 1631. [CrossRef]

28. Boschi, E.; Pantosti, D.; Slejko, D.; Stucchi, M.; Valensise, G. Special issue on the meeting “Irpinia dieci anni dopo", Sorrento, 19-24 November 1990. Ann. Geofis. 1993, 36, 376p.

29. Westaway, R. Fault rupture geometry for the 1980 Irpinia earthquake: A working hypothesis. Ann. Geofis. 1996, 36, 51-69.

30. Amato, A.; Selvaggi, G. Aftershock location and P-velocity structure in the epicentral region of the 1980 Irpinia earthquake. Ann. Geofis. 1993, 36, 3-15.

31. Cinque, A.; Lambiase, S.; Sgrosso, I. Su due faglie nell'alta valle del Sele legate al terremoto del 23.11.1980. Rend. Soc. Geol. Ital. 1981, 4, 127-129.

32. Bollettinari, G.; Panizza, M. Una "faglia di superficie" presso San Gregorio Magno in occasione del sisma de! 23/11/1980 in Irpinia. Rend. Soc. Geol. Ital. 1981, 4, 135-136.

33. Funiciello, R.; Pantosti, D.; Valensise, G. Fagliazione superficiale associata al terremoto irpino del 23/11/1980. Mem. Soc. Geol. Ital. 1998, 41, 1139-1144. 
34. Blumetti, A.M.; Esposito, E.; Ferreli, L.; Michetti, A.M.; Porfido, S.; Serva, L.; Vittori, E. Ground effects of the 1980 Irpinia earthquake revisited: Evidence for surface faulting near Muro Lucano. In Large-Scale Vertical Movements and Related Gravitational Processes; Dramis, F., Farabollini, P., Molin, P., Eds.; Studi Geologici Camerti, 2002; pp. 19-27.

35. Galli, P.; Lagi, A. Lost Earthquakes Between Antiquity and Middle Age. Archeological Indication from Volcei (Southern Apennines); $34^{\circ}$ Convegno Nazionale GNGTS: Trieste, Italy, 2015; pp. 39-46.

36. Stuiver, M.; Reimer, P.J.; Reimer, R. CALIB Radiocarbon Calibration, Execute Version 7.1. 2010. Available online: http://calib.qub.ac.uk/calib/ (accessed on 28 May 2020).

37. Soriano, F. Compsa Romana. Sviluppo Storico e Architettonico. Ph.D. Thesis, University of Verona, Verona, Italy, 2013; 325p.

38. Buonopane, A. L'iscrizione con litterae caelatae del foro di Compsa (Italia, Regio II). Sylloge Epigr. Barc. 2015, 13, 163-178.

39. Bracco, V. Inscriptiones Italiae, Civitates Vallum Silari et Tanagri, Regio III, I, Roma. Poligr. Stato 1974, 208.

40. Manetti, G. 1457. De Terraemotu Libri tres. In Collana Commissione ENEA/ENEL per lo Studio dei Problemi Sismici Connessi con la Realizzazione di Impianti Nucleari; Molin, D., Scopelliti, C., Eds.; Romana Editrice: Rome, Italy, 1983.

41. Pacca, C. Discorso del Terremoto; MS 7/A3; Biblioteca della Società Napoletana di Storia Patria, Fondo sismico: Naples, Italy, N.A. 16th century.

42. Bonito, M. Terra Tremante, Overo Continuatione de' Terremoti dalla Creatione del Mondo Fino al Tempo Presente; Biblioteca di sismologia, Catalogo dei terremoti: Naples, Italy, 1691; 822p.

43. Bertolini, O. Annales Beneventani, 12th Century. BISI 1923, 42, 1-159.

44. Hoffmann, H. Chronica Monasterii Casinensis, 11th century. MGH 1980, 1.II c.11, 189.

45. Guarna, R. 12th century Chronicon. In RIS, VII/1, Citta di Castello-Bologna 1903-35; Garufi, C.A., Ed.; pp. 170-171.

46. Figliuolo, B.; Marturano, A. Terremoti in Italia Meridionale dal IX all'XI secolo. In Contributi per la storia dei terremoti nel Bacino del Mediterraneo; Marturano, A., Ed.; Osservatorio Vesuviano, Istituto Italiano Studi Filosofici, Laveglia, Nocera Inferiore: Naples, Italy, 2002; pp. 33-68.

47. Pescatori, G. Citta dell'Hirpinia. In Le Città Campane Fra Tarda Antichità e Alto Medioevo; Vitolo, G., Ed.; Laveglia Editore: Salerno, Italy, 2005; pp. 283-311.

48. Sgobbo, I. Conza: Ricerche topografiche sull'antica Compsa. Not. Scavi 1938, 98-103.

49. Johannowsky, W. Conza alla Ricerca del Passato, Atti dell'incontro Dibattito (Conza, 11 Agosto 1979); Calitri, Italy, 1982; pp. 7-40.

50. Di Giovanni, V. Compsa tra Irpini e Romani. Ph.D. Thesis, University Federico II, Naples, Italy, 2015; $204 p$.

51. Gargano, G. Ricerche Storiche su Conza Antica; Calitri: Avellino, Italy, 1934; p. 57.

52. Rotili, M. Ricerche archeologiche in Alta Irpinia testimonianze di età romanobarbarica. Romanobarbarica 1995, 13, 297-324.

53. Rotili, M. Archeologia del donjon di Montella. Memorie dell'Accademia di Archeologia Lettere e Belle Arti. 1999, XIII, 25.

54. Galli, P.; Naso, J.A. Unmasking the 1349 earthquake source (southern Italy): Paleoseismological and archaeoseismological indications from the Aquae Iuliae fault. J. Struct. Geol. 2009, 31, 128-149. [CrossRef]

55. Esposito, E.; Porfido, S.; Luongo, G.; Petrazzuoli, S.M. Damage scenarios induced by the major seismic events from XV to XIX century in Naples city with partcular reference to the seismic response. In Earthquake Engineering. Tenth World Conference; Balkema: Rotterdam, The Netherlands, 1992.

56. Seneca, L. Naturales Quaestiones; Vottero, D., Ed.; Torino, Italy, 1989.

57. Nostro, C.; Stein, R.S.; Cocco, M.; Belardinelli, M.E.; Marzocchi, W. Two-way coupling between Vesuvius eruptions and southern Apennine earthquakes, Italy, by elastic stress transfer. J. Geophys. Res. Space Phys. 1998, 103, 24487-24504. [CrossRef]

58. Marturano, A. Sources of ground movement at Vesuvius before the AD 79 eruption: Evidence from contemporary accounts and archaeological studies. J. Volcanol. Geotherm. Res. 2008, 177, 959-970. [CrossRef]

59. Bardario, B. Bucino, Vulcinum, vel Vulceiana Civitas; Archivio Generale degli Agostiniani: Roma, Italy, 1581. 